\title{
ЕКСПЕРИМЕНТАЛЬНІ ДОСЛІДЖЕННЯ ВСТАНОВЛЕННЯ ЗАКОНОМІРНОСТІ ЗНИЖЕННЯ ТЕМПЕРАТУРИ І ПРИПИНЕННЯ ГОРІННЯ ТРАНСФОРМАТОРНОГО МАСЛА ЗАЛЕЖНО ВІД ПАРАМЕТРІВ ГРАВІЙНОЇ ЗАСИПКИ МАСЛОПРИЙМАЧА
}

\author{
https://doi.org/10.33269/nvcz.2021.2.101-110
}

\author{
Климась P. B. ${ }^{,}$ORCID iD 0000-0001-8570-6392 \\ Ніжник B. B. ,ORCID iD 0000-0003-3370-9027 \\ Нікулін О. Ф. ORCID iD 0000-0001-9126-0681 \\ Крикун О. M., ORCID iD 0000-0001-8132-9788 \\ Середа Д. В.ORCID iD 0000-0002-9645-5864 \\ Цимбалістий C. 3. ORCID iD. 0000-0002-9187-1674 \\ *E-mail : r.klymas@undicz.dsns.gov.ua \\ Інститут державного управління та наукових досліджень з цивільного захисту, Україна
}

ІНФОРМАЦІЯ ПРО СТАТТЮ

Надійшла до редакції: 09.11.2021

Пройшла рецензування: 06.12.2021

КЛЮЧОВІ СЛОВА:

трансформаторне обладнання, трансформаторне масло, маслоприймач, гравійна засипка, припинення горіння, охолодження масла.

\begin{abstract}
АНОТАЦІЯ
У статті наведено результати експериментального дослідження щодо виявлення закономірностей зниження температури та припинення горіння трансформаторного масла від параметрів гравійної засипки маслоприймача трансформаторної підстанції, проведеного за методикою експериментальних досліджень 3 обґрунтування мінімальних геометричних параметрів гравійної засипки маслоприймача.

У результаті проведеного експерименту отримано залежність зниження температури $(\Delta \theta)$ трансформаторного масла від відстані його проходження гравійною засипкою маслоприймача.
\end{abstract}

\section{Постановка}

Трансформатори $є$ одними 3 найбільш пожежонебезпечних видів обладнання на маслонаповнених трансформаторних підстанціях. За аварійних режимів роботи або пошкодження цілісності корпусу вони можуть зумовити пожежу. Як правило, такі пожежі супроводжуються аварійним розливом масла із трансформатора і його загорянням, що у подальшому спричиняє розвиток пожежі та іiі поширення на суміжні об'єкти і територією підприємства.

Припинення горіння трансформаторного масла та його охолодження до безпечної температури має досягатися застосуванням системи вогнеперешкоджання, що складається 3 маслоприймача, масловідводів i вогнезагороджувача, в якості якого використовують маслозбірник із металевою решіткою, поверх якої улаштовано гравійну засипку.

На практиці 3 метою попередження розвитку таких пожеж застосовують норму Правил улаштування електроустановок [1] щодо встановлення маслонаповнених трансформаторів у маслоприймачі, дно якого має бути засипаним чистим гравієм чи промитим гранітним щебенем 3 частками розміром від 30 мм до 70 мм. Разом із тим унаслідок впливу довкілля гравійна засипка постійно забруднюється, що погіршує іiі пропускну й охолоджувальну здатність. Зазначене спричиняє іi періодичне збирання, промивання, сушку, повторну засипку, що є економічно затратним, трудомістким i складним у реалізації. 
Відповідно до Правил улаштування електроустановок [1] дозволяється не засипати дно маслоприймачів на всій площі гравієм, але геометричні параметри таких відхилень не зазначені. Це зумовлює необхідність проведення досліджень 3 наукового обгрунтування оптимальних параметрів гравійної засипки маслоприймачів як складової ефективності системи

маслонаповнених вогнеперешкоджання підстанцій в умовах пожежі.

\section{Аналіз останніх досліджень}

i публікацій. 3 огляду на вивчення вітчизняної нормативної бази єдиним нормативним документом, у якому встановлено вимоги до електроустановок загального призначення змінного струму напругою до 750 кВ та постійного струму напругою до 1,5 кВ, зокрема щодо запобігання розтіканню масла та поширенню пожежі під час пошкодження маслонаповнених

силових трансформаторів, є [1]. Згідно 3 аналізом іноземного досвіду щодо обмеження поширення пожеж під час аварій на маслонаповнених трансформаторних підстанціях [2-7] зарубіжні підходи аналогічні вітчизняним.

За результатами проведеного аналізу вимог вітчизняної та зарубіжної нормативної бази щодо конструктивних параметрів площадок маслоприймачів можна стверджувати, що сучасні підходи до обмеження поширення пожежі під час аварій на маслонаповнених трансформаторних підстанціях недосконалі й економічно затратні для мінімізації наслідків горіння розливів трансформаторного масла [8; 9].

Серед вітчизняних i зарубіжних вчених, роботи яких присвячені цій проблематиці, можна виділити А. Булгакова, Д. Варнакову, А. Душкіна, Д. Зозулю, Б. Кашолкіна, Є. Мешалкіна, Marc Foata, які аналізували проблеми запобігання виникненню пожеж та їх гасіння в електроустановках, зокрема на маслонаповнених трансформаторах. Питанням обмеження поширення пожеж на суміжні споруди, оцінювання ризиків виникнення пожеж на трансформаторних підстанціях присвячені роботи В. Ніжника, В. Соколова, С. Поздєєва, Л. Філяновича, А. Хісматулліна, В. Черкасова, Heinz-Peter Berg, Nicole Fritze та інших [10]. Однак у цих працях недостатньо досліджені процеси маслотеплопередачі для забезпечення ефективного відведення тепла трансформаторного масла, що проходить через вогнезагороджувач під час аварії на трансформаторних підстанціях, i не виявлені закономірності зниження температури масла до нижчої за його температуру спалаху залежно від геометричних параметрів гравійної засипки.

3 огляду на викладене проведення досліджень, спрямованих на розкриття закономірностей зниження температури трансформаторного масла та припинення його горіння залежно від параметрів гравійної засипки маслоприймача, $\epsilon$ актуальною науковою задачею, розв'язання якої може бути реалізовано шляхом проведення експерименту. Для його проведення було розроблено методику експериментальних досліджень обгрунтування мінімальних геометричних параметрів гравійної засипки у маслоприймачі трансформаторної підстанції [11], що дає змогу дослідити температуру охолодження трансформаторного масла й умови припинення його горіння під час проходження гравійною засипкою в умовах пожежі.

Методи дослідження. Під час вивчення проблематики зазначеного питання використовувався комплексний метод досліджень, що включав: аналізування довідкових даних i нормативних документів, якими регламентовано методи тепломасообміну між речовинами та матеріалами й обмеження поширення пожеж на суміжні споруди; визначення показників пожежної небезпеки трансформаторного масла проводилося за стандартизованими методами згідно із ДСТУ 8829 [12]; обробляння результатів експериментальних досліджень проводилося методами 
математичної статистики, їх оцінювання методом аналізування на наявність викидів i квазівикидів (Граббса) та методом перевірки належності дисперсій до однієї генеральної сукупності (Фішера); експеримент проведено за розробленим методом дослідження 3 визначення зниження температури масла залежно від параметрів гравійної засипки маслоприймача трансформаторної підстанції.

Мета дослідження полягає в оцінюванні результатів експериментальних досліджень із виявлення закономірностей зниження температури та припинення горіння трансформаторного масла залежно від параметрів гравійної засипки маслоприймача трансформаторної підстанції.

Для досягнення поставленої мети необхідно розв'язати такі задачі:

встановити перелік параметрів, які слід враховувати під час проведення експерименту із виявлення закономірностей зниження температури та припинення горіння трансформаторного масла;

\section{провести}

дослідження експериментальні встановлення закономірностей зниження температури та припинення горіння трансформаторного масла залежно від параметрів гравійної засипки маслоприймача;

оцінити та проаналізувати результати експериментальних досліджень;

виявити залежність зниження температури (Ди) трансформаторного масла від відстані його проходження гравійною засипкою маслоприймача.

\section{Виклад основного матеріалу} дослідження. Експериментальні дослідження 3 виявлення закономірностей зниження температури та припинення горіння трансформаторного масла залежно від параметрів гравійної засипки маслоприймача трансформаторної підстанції проводились за методикою [11], розробленою в межах виконання науководослідної роботи [13].
Попередньо, аналізуючи обставини виникнення пожеж на маслонаповнених трансформаторних підстанціях, було визначено, що на обмеження поширення таких пожеж можуть впливати конструктивні параметри та матеріал маслоприймача, матеріал його засипки, a також природні чинники [10]. Досліджуючи взаємозв'язки між зазначеними параметрами та їх значущість до впливу на процес тепломасообміну між маслом та гравійною засипкою, встановлено перелік параметрів, що слід враховувати під час дослідження залежності зниження температури трансформаторного масла від геометричних параметрів гравійної засипки, а саме - висоти гравійної засипки, ширини гравійної засипки, ухилу маслоприймача у бік маслозбірника.

У цьому експерименті імітується аварійна ситуація у трансформаторі за підвищення температури масла до аварійного значення $\left(T_{\text {самозаймання }} \approx 250{ }^{\circ} \mathrm{C}\right)$, його розгерметизація $з$ подальшим виливом масла у маслоприймач із подальшим загорянням масла. Під час його проведення використовувалося трансформаторне масло типу Nytro 11GX виробництва шведської компанії Nynas $\mathrm{AB}$, що відповідає міжнародному стандарту IEC 60296 [14]. Визначення показників пожежної небезпеки трансформаторного масла за методами згідно з ДСТУ 8829 [12] дало змогу встановити діапазон зниження його температури від аварійного значення до нижчої за $T_{\text {сnалаху }}$ у $150 \mathrm{C}$, що й стало критерієм оцінювання ефективності системи вогнеперешкоджання на маслонаповнених трансформаторних підстанціях в умовах пожежі.

Дослідження проводились за таких умов довкілля: атмосферний тиск 101,3 кПа; відносна вологість повітря 65 \%; температура $30{ }^{\circ} \mathrm{C}$.

Дослідний стенд [11] складається 3 трьох основних блоків, схему якого наведено на рис. 1. 


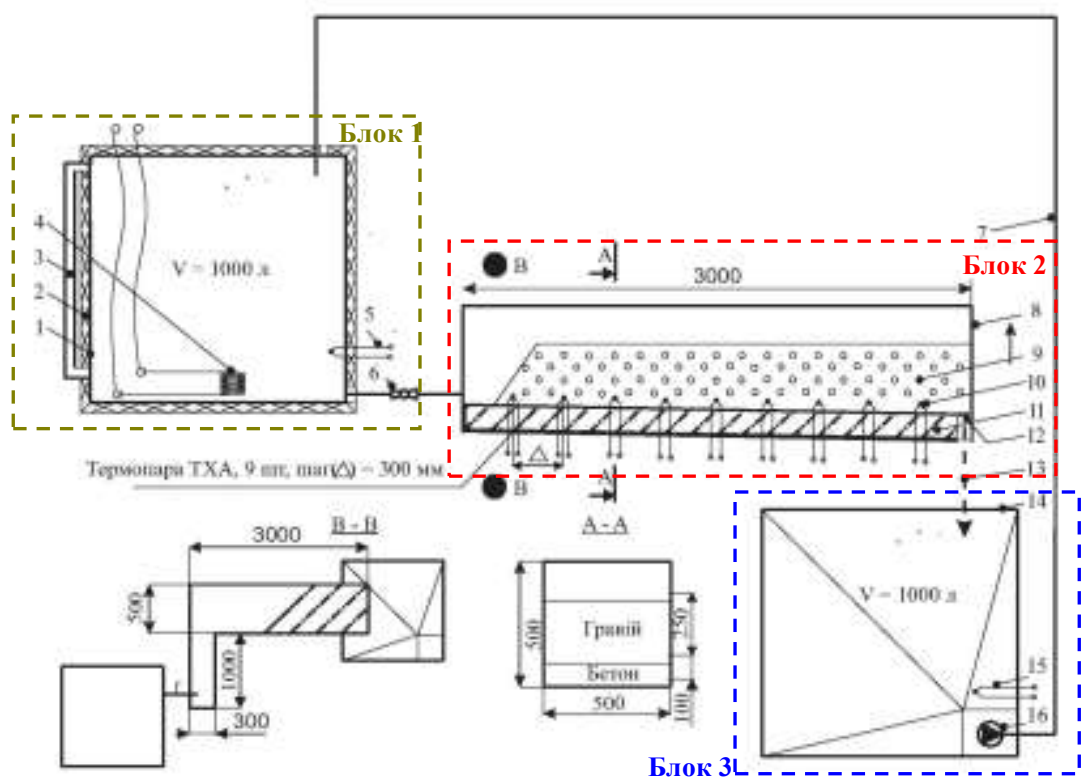

Рисунок 1 - Схема дослідного стенду

1 - корпус ємкості для масла; 2 - теплоізоляція; 3 - кварцова трубка для візуального контролю рівня масла; 4 - ТЕН; 5 - термопара; 6 - шаровий кран; 7 - з'єднувальна арматура; 8 - корпус маслоприймача; 9 - гравійна засипка; 10 - термопари; 11 - бетон; 12 - сітка; 13 - траєкторія зливання масла в аварійну ємність; 14 - корпус аварійної ємкості; 15 - термопара; 16 - шестеренчастий насос

Дюерело: [11]

Блок 1, що імітує аварію в маслонаповненому трансформаторі, складається: з ємності об'ємом 1000 л, в яку заливалося масло, із отвором, що імітує аварійний вилив масла; ТЕНу для нагрівання масла та термопари контролю температури масла. Розмір аварійного отвору визначався 3 аналізу статистичних даних про аварії на трансформаторних підстанціях за останні 10 років. Об'єм масла, що заливався у ємкість, визначався із розрахунку його вільного витікання через заданий отвір упродовж 15 хв, що складав 900 л.

Блок 2 складається із металевого дека, що імітує маслоприймач із гравійною засипкою, iз бетонним дном. Для відтворення найбільш несприятливих умов тепломасообміну бокові стінки корпусу маслоприймача були теплоізольовані шаром мінеральної вати. Для заміру температур у гравійній засипці встановлювалися термопари (TXA) із кроком 300 мм на відстані 10 мм від дна маслоприймача.

Блок 3 являє собою аварійну ємкість для зливання масла.

Принципами проведення експериментальних досліджень визначили таке:

над гравійною засипкою не повинно бути полуменевого горіння парів масла;

температура масла у місці отвору його зливу в аварійну ємкість (маслозбірник) не повинна перевищувати $150{ }^{\circ} \mathrm{C}$.

Дослідний стенд під час проведення експерименту зображено на рис. 2. 


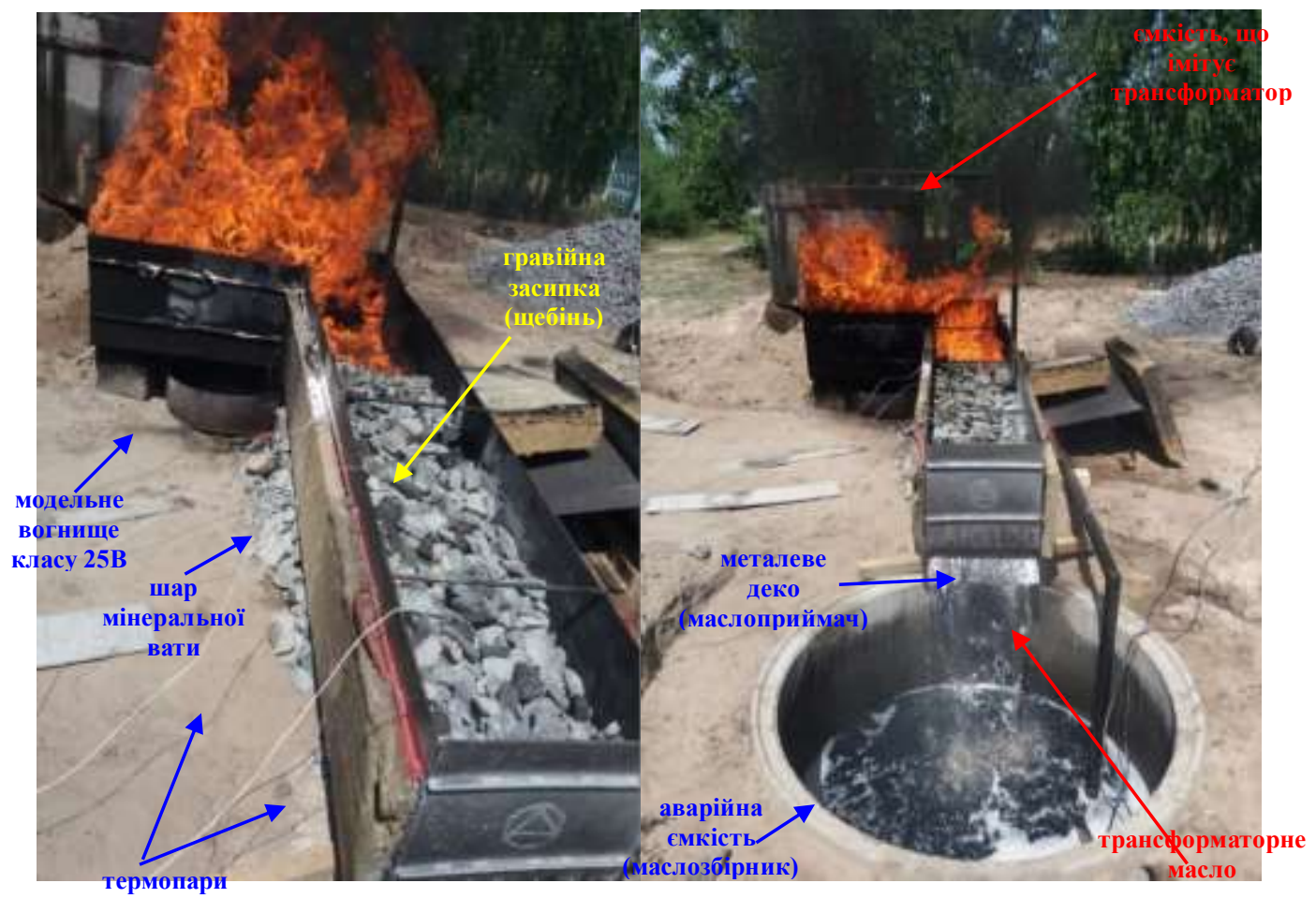

Рисунок 2 - Зображення дослідного стенду під час проведення експерименту

Джерело: розроблено авторами

Порядок підготовки до проведення експерименту детально описано в роботі [11].

Проведення

експерименту

здійснювалось у такій послідовності:

за досягнення маслом у ємкості (1), що імітує трансформатор, температури, наближеної до аварійних значень $\left(\approx 250^{\circ} \mathrm{C}\right)$, відкривався шаровий кран (6), за допомогою якого регулювалася така необхідна витрата масла, щоб ємкість була звільнена за 900 с;

паралельно дно маслоприймача (8) підігрівалося горінням бензину А92 в модельному вогнищі класу 25B;

під час потрапляння масла до маслоприймача відбувалось його займання, і в цей момент розпочиналось вимірювання показників температур термопарами $(5,10,15)$, що розташовані у маслоприймачі (8), в отворі зливу масла в аварійну ємкість (14) і в корпусі ємкості для масла (1); за допомогою інформаційновимірювальної системи «Термоконт» фіксувалося зниження температури масла під час його проходження гравійною засипкою (9), а наявність полуменевого горіння парів масла над іiі поверхнею Таблиия 1 - Виміряні та середні значення температур трансформаторного масла залежно від відстані його проходження гравійною засипкою маслоприймача фіксувалася візуально та засобом фото-, відеофіксації (фотовідеокамера Nikon D3110 18-55VR Kit);

тривав до моменту повного витікання

Експериментальні дослідження із проходження трансформаторного масла через гравійну засипку маслоприймача у маслозбірник повторювали шість разів, змінюючи ширину гравійної засипки від 300 мм до 2400 мм із кроком у 300 мм. Повторювання експерименту забезпечувалося заповненням першої ємкості трансформаторним маслом шляхом його перекачування 3 аварійної ємкості (маслозбірника) за допомогою електронасоса, що приводився в дію асинхронним двигуном.

Результати кожного експерименту фіксувалися окремо 3 визначенням середнього значення.

Результати

експериментальних досліджень зі встановлення закономірностей зниження температури трансформаторного масла залежно від відстані його проходження гравійною засипкою маслоприймача наведено $\mathrm{y}$ табл. 1. масла із ємкості (1). 


\begin{tabular}{|c|c|c|c|c|c|c|c|c|c|c|}
\hline \multirow{2}{*}{\begin{tabular}{c}
\multirow{2}{*}{$\begin{array}{c}\text { № } \\
\text { експер. }\end{array}$} \\
\cline { 2 - 10 }
\end{tabular}} & 0 & 300 & 600 & 900 & 1200 & \multicolumn{1}{|c|}{1500} & 1800 & 2100 & 2400 \\
\cline { 2 - 10 } & \multicolumn{8}{|c|}{ Значення температур трансформаторного масла, ${ }^{\circ} \mathbf{C}$} \\
\hline 1 & 262 & 229 & 188 & 169 & 135 & 130 & 127 & 122 & 118 \\
\hline 2 & 256 & 234 & 193 & 157 & 140 & 134 & 129 & 123 & 119 \\
\hline 3 & 254 & 236 & 198 & 163 & 139 & 133 & 128 & 122 & 116 \\
\hline 4 & 267 & 240 & 203 & 172 & 144 & 136 & 130 & 124 & 120 \\
\hline 5 & 251 & 233 & 196 & 161 & 149 & 138 & 133 & 123 & 119 \\
\hline 6 & 259 & 242 & 205 & 179 & 152 & 139 & 134 & 125 & 121 \\
\hline Сер. знач. & 258 & 235 & 197 & 167 & 143 & 135 & 130 & 123 & 118 \\
\hline
\end{tabular}

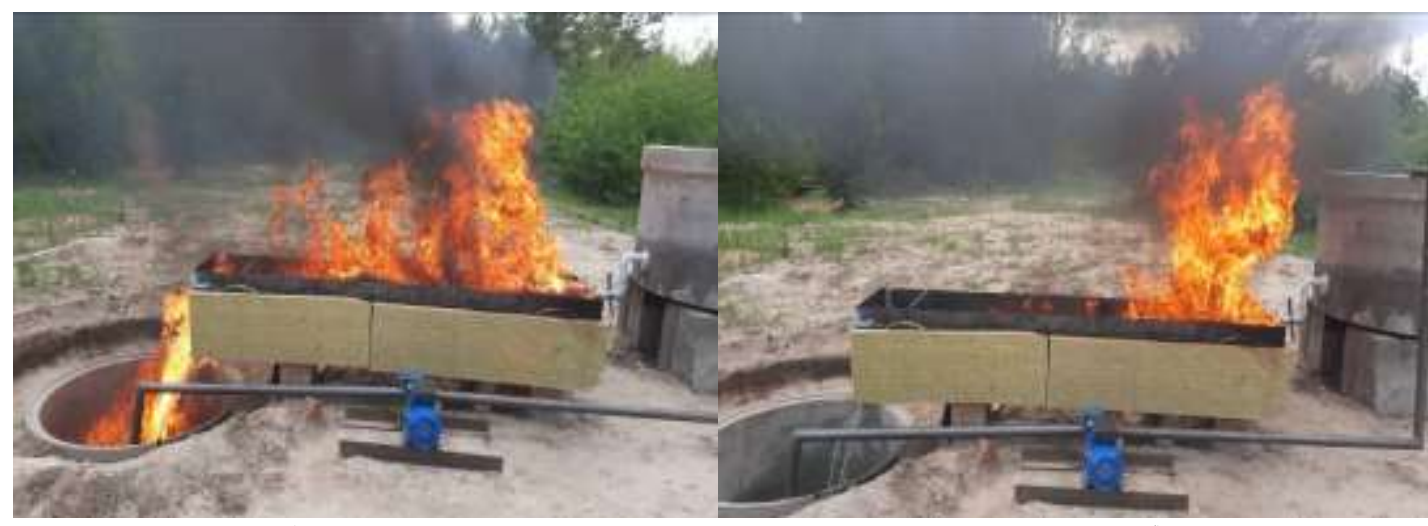

a)

б)

Рисунок 3 - Візуалізація горіння трансформаторного масла у разі його проходження гравійною засипкою маслоприймача під час проведення експерименту на дослідному стенді:

a) горіння масла не припиняється $\left(d_{\Gamma 3} \leq 1200\right.$ мм);

б) горіння масла припиняється $\left(d_{\Gamma 3} \approx 1500\right.$ мм $)$

Джерело: розроблено авторами

Полуменеве горіння парів масла над гравійною засипкою спостерігалося за іiі ширини менше ніж 1200 мм. У разі ширини гравійної засипки 1500 мм горіння парів масла над іï поверхнею припинялося.

Ефективність охолодження та припинення горіння трансформаторного масла залежно від відстані проходження гравійною засипкою маслоприймача зображено на рис. 3. На основі отриманих експериментальних даних, наведених $\mathrm{y}$ табл. 1, побудовано графік залежності зниження температури трансформаторного масла від відстані його проходження гравійною засипкою маслоприймача та їх середні значення (рис. 4) [15].

Під час проведення експериментів діапазон коливання температур складав не більше $10{ }^{\circ} \mathrm{C}$. Температура масла на вході до гравійної засипки перевищувала значення у $250{ }^{\circ} \mathrm{C}$ та знижувалася до $116^{\circ} \mathrm{C}$ на виході з гравійної засипки (в місці зливу в аварійну ємкість).

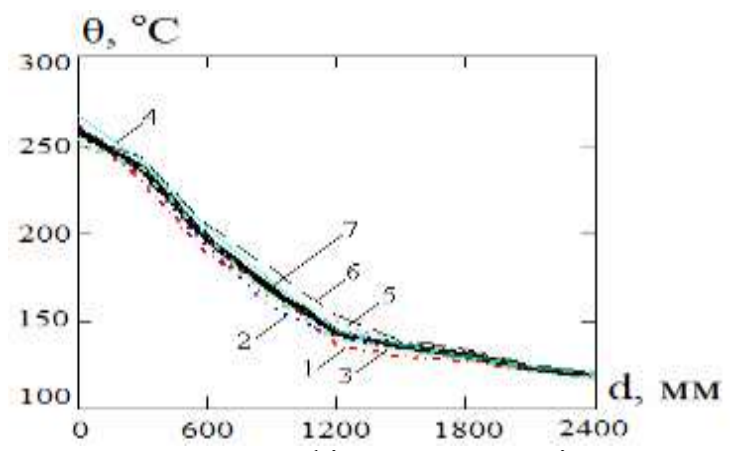

Рисунок 4 - Графік залежності зниження температури трансформаторного масла від відстані проходження гравійною засипкою:

1 - крива проведення першого експерименту;

2 - крива проведення другого експерименту;

3 - крива проведення третього експерименту;

4 - крива проведення четвертого експерименту;

5 - крива проведення п'ятого експерименту;

6 - крива проведення шостого експерименту;

7 - усереднена крива всіх шести експериментів

Джерело: розроблено авторами

Обробку

результатів

експериментальних досліджень проводили методами математичної статистики в два етапи. На першому етапі проводилася перевірка результатів експериментальних 
досліджень на наявність викидів i квазівикидів. На другому етапі проводилося порівняння результатів експериментальних досліджень для виявлення розбіжностей між дисперсіями.

Для виявлення у результатах експериментальних досліджень викидів та квазівикидів застосували критерій Граббса (1):

$$
G_{\max }=\frac{y_{\max }-\bar{y}}{S} \text { та } G_{\min }=\frac{\bar{y}-y_{\min }}{S}
$$

де: $\bar{y}$ - середнє значення;

$S$ - середньо квадратичне відхилення.

У нашому випадку критичні значення (для $n=6$ експериментів) для критерію Граббса складають: для $5 \%-1,973$ та для $1 \%-1,887$ відповідно.

Отримані розрахункові значення $G_{\max }$ та $G_{\text {min }}$ для всіх випадків залежно від відстані проходження трансформаторного масла гравійною засипкою є меншими за критичні. Тобто результати експериментальних досліджень не містять викидів та квазівикидів за критерієм Граббса.

Для комплексного оцінювання результатів шести експериментів застосували критерій Фішера (2), порівнявши при цьому отриману оцінку дисперсії для першого та наступних експериментів (1 та 2; 1 та $3 ; 1$ та 4; 1 та $5 ; 1$ та 6):

$$
F=\frac{S_{1}^{2}}{S_{2}^{2}}
$$

де: $S_{1}^{2}, S_{2}^{2}$-оцінка дисперсій для значень, отриманих під час експериментів.

Дисперсії відхилень за середнім значенням температур трансформаторного масла залежно від відстані його проходження гравійною засипкою маслоприймача наведено на рис. 5.

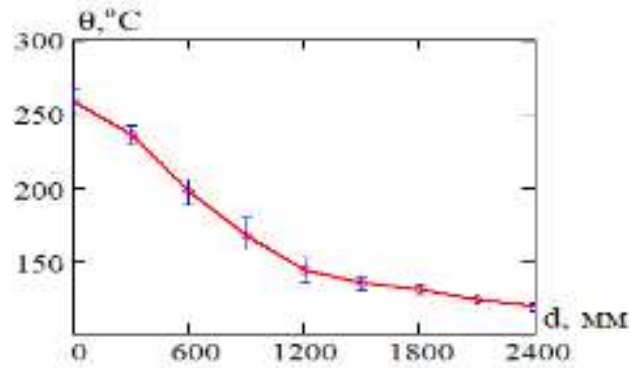

Рисунок 5 - Дисперсії відхилень за середнім значенням температур трансформаторного масла від відстані проходження гравійною засипкою

Джерело: розроблено авторами

У разі одержання розрахункових значень, що $є$ меншими від критичних за критерієм Фішера, слід вважати, що отримані результати експериментальних досліджень належать до однієї генеральної сукупності та суттєво не відрізняються між собою.

Критичним значенням для критерію Фішера для кількості ступенів $k_{1}=8$ та $k_{2}=8$ $\epsilon$ значення 3,44. Отримані розрахункові значення за критерієм Фішера менші за критичні. Тобто результати експериментальних досліджень належать до однієї генеральної сукупності та суттєво не відрізняються між собою.

Таким чином, за результатами експериментальних досліджень встановлено, що залежність зниження температури (Ди) трансформаторного масла залежно від відстані від входу у гравійну засипку маслоприймача до маслозбірника має вигляд рівняння (3):

$$
\Delta \theta=263,16-39,1 d+2,7 d^{2}-0,005 d^{3}
$$

На основі результатів експериментальних досліджень і даних математичного моделювання [10] побудовано залежність зниження температури трансформаторного масла від відстані проходження через гравійну засипку (від точки входу масла в гравійну засипку до точки виходу в місці зливу в аварійну ємність), наведену на рис. 6. 


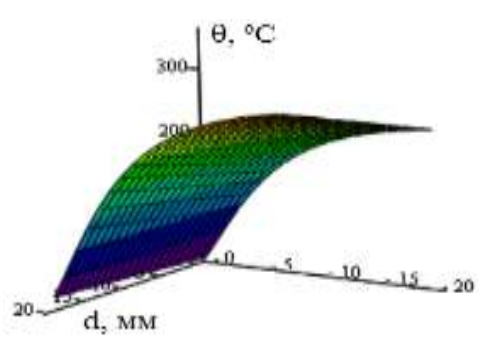

Рисунок 6 - Залежність зниження температури трансформаторного масла на основі усереднених даних математичного моделювання й експериментальних досліджень Джерело: розроблено авторами $\begin{array}{crr}\text { Таким } & \text { чином, } & \text { експериментально } \\ \text { підтверджено } & \text { дані, } & \text { отримані }\end{array}$ результатами математичного моделювання [10], стосовно того, що зниження температури масла від $250 \mathrm{C}$ до $150{ }^{\circ} \mathrm{C}$ забезпечують мінімальні розміри гравійної засипки шириною 1500 мм і висотою $250 \mathrm{MM}$.

\section{Висновки та напрями подальших} досліджень. У результаті проведених експериментальних досліджень 3 виявлення закономірностей зниження температури та припинення горіння трансформаторного масла залежно від параметрів гравійної засипки маслоприймача трансформаторної підстанції встановлено, що залежність зниження температури масла від відстані від входу у гравійну засипку маслоприймача до маслозбірника має вигляд рівняння: Ди=263,16-39, $1 d+2,7 d^{2}$ $0,005 d^{3}$.

Відхилення кожного результату експерименту не перевищувало $5{ }^{\circ} \mathrm{C}$, що у відносних значеннях становить близько 2,5\%, а критерій Фішера не перевищив значення одиниці, що вказує на те, що отримані результати в кожному експериментальному дослідженні $\epsilon$ вибірками однієї генеральної сукупності, та підтверджує загальну збіжність кожного окремого експериментального дослідження.

3 урахуванням даних попередньо проведеного математичного моделювання експериментально підтверджено та вперше встановлено, що зниження температури трансформаторного масла від $250{ }^{\circ} \mathrm{C}$ до $150{ }^{\circ} \mathrm{C}$ забезпечують мінімальні розміри гравійної засипки шириною 1500 мм i висотою 250 мм.

У подальшому для остаточного обгрунтування параметрів гравійної засипки системи вогнеперешкоджання трансформаторної підстанції, що забезпечують припинення горіння трансформаторного масла та його охолодження до безпечної температури, необхідно провести експериментальні дослідження 3 визначення ефективного ухилу маслоприймача у бік маслозбірника

\section{СПИСОК ВИКОРИСТАНИХ ДЖЕРЕЛ}

1. Правила улаштування електроустановок. Київ : Міненерговугілля України, 2017. 617 с.

2. Правила устройства электроустановок. Астана : Министерство энергетики и минеральных ресурсов Республики Казахстан, 2015.391 c.

3. Правила устройства электроустановок. М. : Министерство энергетики Российской Федерации, 2003. 499 с.

4. ТКП 339-2011 (02230). Электроустановки на напряжение до 750 кВ. Линии электропередачи воздушные и токопроводы, устройства распределительные и трансформаторные подстанции, установки электросиловые и аккумуляторные, электроустановки жилых и общественных зданий. Правила устройства и защитные меры электробезопасности. Учет электроэнергии. Нормы приемо-сдаточных испытаний. Минск : Министерство энергетики Республики Беларусь. 2011. $600 \mathrm{c}$.

5. Transformer Fire Protection. Facilities Instructions, Standards and Techniques. Vol. 3-32. U.S. Department of the Interior Bureau of Reclamation Denver, Colorado, January 2005. 43 p.

6. Construction of 33/11kv substations. Section (1). Technical specifications. The Republic of Iraq Ministry of electricity (MoE) energy distribution office, March 2012. 222 p.

7. Guide for Transformer Fire Safety Practices. Working Group A2.33. Cigre, Paris, France, June 2013. 139 p.

8. Некора В. С., Стилик І. Г., Ніжник В. В. Аналіз нормативних підходів щодо обмеження поширення пожежі під час аварій на маслонаповнених трансформаторних підстанціях. Проблеми та перспективи розвитку системи безпеки життєдіяльності : зб. наук. праць XVI Міжнар. наук.-практ. конф. молодих вчених, курсантів та студентів. Львів : ЛДУ БЖД, 2021. С. 84-85.

9. Климась Р. В., Ніжник В. В. Дослідження існуючих підходів до обмеження поширення пожеж на трансформаторних підстанціях. Надзвичайні ситуаиї: безпека та захист : матеріали XI Всеукр. наук.-практ. конф. $з$ міжнар. участю. Черкаси : ЧІПБ ім. Героїв Чорнобиля НУЦЗ України, 2021. С. 31-33. 
10. Justification of minimum parameters of gravel backfill of the oil receiver of the transformer substation / R. Klymas, V. Nizhnyk, O. Nekora, V. Nekora, I. Stylyk. The Scientific heritage. Budapest, Hungary. Vol. 3. № 79(79). 2021. P. 36-44.

11. Методика експериментальних досліджень обгрунтування мінімальних геометричних параметрів гравійної засипки у маслоприймачі трансформаторної підстанції / Р. Климась, та ін. Науково-технічний збірник : Комунальне господарство міст. Серія : технічні науки та архітектура. Харків. Т. 4. Вип. 164. 2021. С. 158-165.

12. ДСТУ 8829:2019. Пожежовибухонебезпечність речовин і матеріалів. Номенклатура показників і методи їхнього визначення. Класифікація. [Чинний від 2020-01-01]. Київ : УкрНДНЦ, 2020. 78 с.

13. Обгрунтувати мінімальні геометричні параметри (висота та периметр) засипки гравію у маслоприймачі над маслоприймальним каналом, яка повинна виконувати функцію вогнезагороджувача та охолодження мастила до температури спалаху 150 градусів Цельсія в рамках розробки робочої документації по об'єкту «Реконструкція ПС 330 кВ Броварська з установкою АТ-3» / ДСНС України, ІДУ НД ЦЗ; керівник : В. В. Ніжник. Київ, 2021. 129 с. ДР $0121 \mathrm{U} 100682$. Iнв. № 0113 U004330.

14. IEC 60296:2003. Fluids for electrotechnical applications - Unused mineral insulating oils for transformers and switchgear. [International Standard]. URL : https://webstore.iec.ch/publication/14600 (last accessed : 01.10.2021).

15. Макаров Е. Г. Инженерные расчеты в Mathcad 15 : уч. курс. СПб : БГТУ Военмех, 2011. 345 с.

\section{REFERENCES}

1. Pravyla ulashtuvannya elektroustanovok [Rules for Arrangement of Electrical Installations] (2017). Kyiv: Minenergovugillya of Ukraine [in Ukrainian].

2. Pravila ustroystva elektroustanovok [Rules for Arrangement of Electrical Installations] (2015). Astana: Ministry of Energy and Mineral Resources of the Republic of Kazakhstan [in Russian].

3. Pravila ustroystva elektroustanovok [Rules for Arrangement of Electrical Installations] (2003). Moscow: Ministry of Energy of the Russian Federation [in Russian].

4. TKP 339-2011 (02230). Elektroustanovki na napryazheniye do $750 \mathrm{kV}$. Linii elektroperedachi vozdushnyye i tokoprovody, ustroystva raspredelitel'nyye i transformatornyye podstantsii, ustanovki elektrosilovyye i akkumulyatornyye, elektroustanovki zhilykh i obshchestvennykh zdaniy. Pravila ustroystva i zashchitnyye mery elektrobezopasnosti. Uchet elektroenergii. Normy priyemo-sdatochnykh ispytaniy [Electrical installations for voltages up to $750 \mathrm{kV}$. Overhead power lines and conductors, distribution devices and transformer substations, power and battery installations, electrical installations of residential and public buildings. Rules for arrangement and protective measures for electrical safety. Electricity metering. Acceptance test standards] (2011). Minsk: Ministry of Energy of the Republic of Belarus [in Russian].

5. Transformer Fire Protection. Facilities Instructions, Standards and Techniques. Volume 3-32. (2005). U.S. Department of the Interior Bureau of Reclamation Denver, Colorado [in English].

6. Construction of 33/11kv substations. Section (1). Technical specifications (2012). The Republic of Iraq Ministry of electricity (MoE) energy distribution office [in English].

7. Guide for Transformer Fire Safety Practices (2013). Working Group A2.33. Cigre, Paris, France [in English].

8. Nekora, V. S., Stylyk, I. G., \& Nizhnyk, V. V. (2021). Analiz normatyvnykh pidkhodiv shchodo obmezhennia poshyrennia pozhezhi pid chas avarii na maslonapovnenykh transformatornykh pidstantsiiakh [Analysis of normative approaches to limit the spread of fire during accidents at oil-filled transformer substations]. Problemy ta perspektyvy rozvytku systemy bezpeky zhyttiediialnosti: Zb. nauk. prats XVI Mizhnar. nauk.-prakt. konf. molodykh vchenykh, kursantiv ta studentiv [Problems and prospects for the development of life safety system: Coll. Science. works of the XVI International. scientific-practical conf. young scientists, cadets and students]. Lviv: LSU of LS [in Ukrainian].

9. Klymas, R. V., \& Nizhnyk, V. V. (2021). Doslidzhennia isnuiuchykh pidkhodiv do obmezhennia poshyrennia pozhezh na transformatornykh pidstantsiiakh [Research of existing approaches to limiting the spread of fires at transformer substations]. Nadzvychaini sytuatsii: bezpeka ta zakhyst: Materialy XI Vseukrainskoi naukovo-praktychnoi konferentsii z mizhnarodnoiu uchastiu [Emergencies: Security and Protection: Proceedings of the XI All-Ukrainian Scientific and Practical Conference with International Participation]. Cherkasy: ChI of FS n.a Chornobyl Heroes of NUCDU [in Ukrainian].

10. Klymas, R. V., Nizhnyk, V. V., Nekora, O. V., Nekora, V. S., \& Stylyk, I. G. (2021) Justification of minimum parameters of gravel backfill of the oil receiver of the transformer substation. The Scientific heritage. Budapest, Hungary [in English].

11. Klymas, R. V., Nizhnyk, V. V., Ballo, Ya. V., Khromenkov, D. G., Gulyk, Yu. B., \& Ilchenko, N. M. (2021). Metodyka eksperymentalnykh doslidzhen obgruntuvannia minimalnykh heometrychnykh parametriv hraviinoi zasypky u maslopryimachi transformatornoi pidstantsii [Methods of experimental research justification of minimum geometric parameters of gravel backfill in the oil receiver of the transformer substation]. Naukovo-tekhnichnyi zbirnyk: Komunalne hospodarstvo mist. Seriia: tekhnichni nauky ta arkhitektura [Scientific and technical collection: Municipal services of cities. Series: technical sciences and architecture]. Kharkiv [in Ukrainian].

12. DSTU 8829:2019. Pozhezhovybukhonebezpechnist rechovyn i materialiv. Nomenklatura pokaznykiv i metody yikhnoho vyznachennia. Klasyfikatsiia [Fire and explosion hazard of substances and materials. Nomenclature of indicators and methods of their definition. Classification]. Valid from 2020-01-01. (2020). Kyiv: SE «UkrNDNC» [in Ukrainian].

13. Obgruntuvaty minimalni heometrychni parametry (vysota ta perymetr) zasypky hraviiu u maslopryimachi nad maslopryimalnym kanalom, yaka povynna vykonuvaty funktsiiu vohnezahorodzhuvacha ta okholodzhennia mastyla do temperatury spalakhu 150 hradusiv Tselsiia v ramkakh rozrobky robochoi dokumentatsii po obiektu «Rekonstruktsiia PS $330 \mathrm{kV}$ Brovarska z ustanovkoiu AT-3» [Justify the minimum geometric parameters (height and perimeter) of gravel backfill in the oil sump above the oil intake channel, which should act as a fire barrier and oil cooling to a flash point of 150 degrees Celsius in the development of working documentation for the object «Reconstruction of $330 \mathrm{kV}$ Brovarska 3»] (2021) / SES of Ukrain IPARP [in Ukrainian].

14. IEC 60296:2003 Fluids for electrotechnical applications - Unused mineral insulating oils for transformers and switchgear (2003).

15. Makarov, Ye.G. (2011) Inzhenernyye raschety v Mathcad 15: Uchebnyy kurs [Engineering Calculations in Mathcad 15: Tutorial]. Sankt-Peterburg: BGTU [in Russian]. 


\title{
EXPERIMENTAL RESEARCH OF ESTABLISHMENT \\ OF THE REGULARITY OF TEMPERATURE REDUCTION AND STOPPING OF THE COMBUSTION OF TRANSFORMER OIL DEPENDING ON THE PARAMETERS OF GRAVEL BACKFILL OF THE OIL RECEIVER
}

\author{
R. Klymas, .V. Nizhnyk, O. Nikulin, O. Krykun, D. Sereda, S. Tsymbalistiy \\ Institute of Public Administration and Research in Civil Protection, Ukraine
}

\section{KEYWORDS \\ transformer equipment, transformer oil, oil receiver, gravel backfill, cessation of combustion, oil cooling.}

\begin{abstract}
ANNOTATION
In case of emergency operation or damage to the integrity of the transformer housing, they may cause a fire. Fire statistics show that $50 \%$ of fires in the energy sector are transformer equipment; as a rule, such fires are accompanied by emergency oil spill from the transformer and its ignition. Existing approaches to limiting the spread of fire during accidents at oil-filled transformer substations are insufficient and cost-effective to minimize the consequences of spillage of burning transformer oil. At the same time, a number of design parameters were identified that negatively affect the effectiveness of fire control. In particular, the rules for the arrangement of electrical installations provide for the provision of electrical substations with oil receivers, which are covered with gravel, which is constantly polluted due to environmental influences, which impairs its capacity and cooling capacity. Structural and geometrical parameters of oil receivers with oil drainage by oil drains, determined by the rules of arrangement of electrical installations, can be the subject of scientific research to improve them. The article presents the results of an experimental study to identify patterns of reduction of the combustion temperature of transformer oil to a temperature below the flash point of the oil depending on the geometric parameters of the gravel backfill of the oil pan during draining the oil into the emergency tank. The essence of the method of experimental research is to identify patterns of reduction of the combustion temperature of transformer oil to a temperature below the flash point depending on the geometric parameters of the gravel backfill when draining the oil into the emergency tank (oil tank).
\end{abstract}

